\title{
Changes of Rheological Properties of Cuttlefish and Squid Meat by Heat Treatment
}

\author{
Yoshinori Mochizuki, ${ }^{* 1}$ Haruo Mizuno, ${ }^{* 1}$ Hiroo Ogawa, ${ }^{* 1}$ \\ Kazuo Ishimura, ${ }^{* 2}$ Hideki Tsuchiya, ${ }^{* 2}$ and Naomichi Iso ${ }^{* 1}$ \\ ${ }^{*}$ Department of Food Science and Technology, Tokyo University of Fisheries, \\ Konan, Minato, Tokyo 108, Japan \\ *2Shiogama Laboratory, Kyokuyo Co., Ltd., Shinhama, Shiogama, Miyagi 985, Japan
}

(Received October 21, 1994)

The changes of rheological properties of a cuttlefish and four squids by heat treatment were studied by the differential scanning calorimetry (DSC), the rupture test, and the stress relaxation test. The thermograms of raw "ika" mantle meat showed three major endothermic peaks at $50^{\circ} \mathrm{C}, 57^{\circ} \mathrm{C}$, and $74^{\circ} \mathrm{C}$. The first and second peaks mainly corresponded with the denaturation of myosin and collagen. The third peak was that of actin which was almost native up to $63^{\circ} \mathrm{C}$, while the other proteins had been completely denatured below $63^{\circ} \mathrm{C}$. The thermograms for all samples indicated that the denaturation of mantle meat had been completed up to $80^{\circ} \mathrm{C}$. Then, the rheological properties were measured for raw meat and heated meat at $63^{\circ} \mathrm{C}$ or $80^{\circ} \mathrm{C}$. A positive correlation between the content of crude protein and the instantaneous elastic modulus was only found in heated meat at $63^{\circ} \mathrm{C}$. It is considered that this relationship was associated with the amount of remaining native actin.

Key words: cuttlefish, squid, DSC, rheology

A major change of meat texture during heat treatments is induced by the thermal denaturation of muscle proteins. In differential scanning calorimetry (DSC), the heat denaturation of muscle proteins is detected as an endothermic peak on the thermogram.

DSC has been used for studies on the thermal transition of proteins in muscle tissue as well as in isolated muscle proteins from rabbit, beef, carp, and chicken, etc. For example, Wright et al. attributed the endothermic transitions to the protein denaturation of rabbit back muscles." Stabursvik et al. found that the differences of myosin thermal transition between red and white muscles were greater than those between muscles from different animal species, while all muscles gave similar actin thermal transition. ${ }^{2)}$ Martens et al. reported the relationships between the thermal transition and sensory texture of bovine muscle; firmness of bovine muscle increased with thermal denaturation of the myofibrillar proteins. Fiber cohesiveness decreased with collagen denaturation. Reduction in juiciness of bovine muscle was primarily associated with actin denaturation. ${ }^{3)}$ For carp back muscles and its isolated myosin and actin, the thermograms were similar to those for bovine muscle and its constituent proteins. ${ }^{4)}$ The observed thermal curves of a chicken broiler and its isolated protein fractions indicated that the thermal transitions in muscle corresponded to the denaturation of myosin, sarcoplasmic proteins, collagen, and F-actin."

It is experimentally well-known that the heating temperature is the most important factor for sensory texture of meat in processing foods. However, the mechanism of the changes in rheological properties of meat in processing foods has not been clarified.

We characterized the rheological properties of cuttlefish and raw squid meat on a previous study. ${ }^{6}$ In this study, we applied the DSC technique to the studies on the structural denaturation of those mantle meats. Then, we investigated the relationships between the composition changes of mantle meat and the changes of rheological properties of the mantle meat by heating.

\section{Materials and Methods}

\section{Materials}

A cuttlefish, "kou ika" Sepia esculenta and four squids, "yari ika" Loligo bleekeri, "Argentine matsu ika" Illex ar. gentinus, "surume ika" Todarodes pacificus, and "New Zealand surume ika" Nototodaus sloani sloani were used in this work. They were immediately frozen after fishing, transported, and stored at $-20^{\circ} \mathrm{C}$ until use. They were of commercial size as listed on Table 1. Mantles with surface skin were removed from the bodies after thawing at room temperature.

Table 1. Materials

\begin{tabular}{|c|c|c|c|}
\hline Sample name & $\begin{array}{l}\text { Collecting date } \\
\text { and location }\end{array}$ & $\begin{array}{c}\text { Total } \\
\text { weight } \\
\text { (g) }\end{array}$ & $\begin{array}{l}\text { Mantle } \\
\text { thickness } \\
\text { (cm) }\end{array}$ \\
\hline $\begin{array}{l}\text { "kou ika" } \\
\text { Sepia esculenta }\end{array}$ & $\begin{array}{l}\text { Jun. } 1992 \\
\text { Tsu-shima }\end{array}$ & $240 \pm 12$ & $0.67 \pm 0.18$ \\
\hline $\begin{array}{l}\text { "yari ika" } \\
\text { Loligo bleekeri }\end{array}$ & $\begin{array}{l}\text { Jun. } 1992 \\
\text { East China Sea }\end{array}$ & $440 \pm 32$ & $0.60 \pm 0.11$ \\
\hline $\begin{array}{l}\text { "Argentine matsu ika" } \\
\text { Illex argentinus }\end{array}$ & $\begin{array}{l}\text { Mar. } 1992 \\
\text { Falkland }\end{array}$ & $450 \pm 25$ & $0.50 \pm 0.07$ \\
\hline $\begin{array}{l}\text { "surume ika" } \\
\text { Todarodes pacificus }\end{array}$ & $\begin{array}{l}\text { Aug. } 1992 \\
\text { Japan Sea }\end{array}$ & $490 \pm 48$ & $0.66 \pm 0.13$ \\
\hline $\begin{array}{c}\text { "New Zealand surume ika" } \\
\text { Nototodaus sloani sloani }\end{array}$ & $\begin{array}{l}\text { Mar. } 1992 \\
\text { New Zealand }\end{array}$ & $450 \pm 27$ & $0.72 \pm 0.15$ \\
\hline
\end{tabular}

The values are expressed as mean \pm S.D. of six to nine mantles. 
Three or four rectangular specimens $(c a .3 \times 3 \mathrm{~cm}$ ) of different thickness were prepared from each mantle of a cuttlefish and four squids for the measurement of chemical composition and rheological properties. The specimens of each mantle were packed in a polyethylen pouch without air, then placed into a hot water bath at $63^{\circ} \mathrm{C}$ or $80^{\circ} \mathrm{C}$ for $30 \mathrm{~min}$. After heating they were quickly cooled to room temperature in ice water.

\section{Differential Scanning Calorimetry (DSC)}

DSC measurement was performed on a SSC-560U. (Seiko Electronic Inc.) Samples (ca. $15 \mathrm{mg}$ ) of ground meat were accurately weighed in aluminum pans which had been treated for oxidation-proof at $120^{\circ} \mathrm{C}$ for $10 \mathrm{~min}$, then sealed with a crimpler. Distilled water was used as a reference sample. Two standards were used for temperature and enthalpy change calibration: gallium $\left(T_{m}=\right.$ $\left.29.8^{\circ} \mathrm{C}, \Delta \mathrm{H}=80.22 \mathrm{~J} / \mathrm{g}\right)$ and benzophenone $\left(\mathrm{T}_{\mathrm{m}}=\right.$ $\left.48.0^{\circ} \mathrm{C}, \Delta \mathrm{H}=98.39 \mathrm{~J} / \mathrm{g}\right)$. The heating conditions of samples were programmed at a heating rate of $2^{\circ} \mathrm{C} / \mathrm{min}$ over the range of $10-120^{\circ} \mathrm{C}$. Each sample was cooled and rescanned to provide a measure of reversible transitions and a base line for analysis. Rescanned thermograms were subtracted to compensate for changes in the base line from the initial scan. DSC thermograms were normalized from three replicates.

\section{Measurement of Chemical Composition}

The water content of the materials was measured by a drying method at $105^{\circ} \mathrm{C}$ for $5 \mathrm{~h}$ with three replicates. The crude fat content was determined by the Soxhlet extraction method with an ethyl ether for $18 \mathrm{~h}$. The crude protein content was determined by the Kjeldahl method. The factor 6.25 was used to convert the obtained amount of nitrogen to the crude protein content.

\section{Measurement of Rheological Properties}

Three or four rectangular specimens $(c a .3 \times 3 \mathrm{~cm})$ of different thickness were prepared from each mantle of three samples of a cuttlefish and squids. The rheological properties were measured at room temperature by using a Tensipresser TTP-50BX. (Taketomo Electric Co., Ltd.) The rupture strength was measured with a conical plunger (angle $45^{\circ}$ ), penetrating at $0.2 \mathrm{~cm} / \mathrm{s}$ of a crosshead speed into the samples. The rupture strength and the rupture power were defined as the rupture force per $1.0 \mathrm{~cm}$ and the rupture work per second, respectively. ${ }^{\text {9 }}$ In the stress relaxation test, the displacement at $20 \%$ depth of sample thickness was kept linear, with a cylindrical plunger (diameter $1.8 \mathrm{~cm}$ ) penetrating at the same crosshead speed. The stress relaxation curves were analyzed by the progressive approximate method based on the Maxwell model. ${ }^{7}$

\section{Results and Discussion}

\section{Differential Scanning Calorimetry (DSC)}

The DSC thermogram of raw "kou ika" mantle meat is shown in Fig. 1-(a). The thermogram consisted of three major endothermic peaks at $50^{\circ} \mathrm{C}, 57^{\circ} \mathrm{C}$, and $74^{\circ} \mathrm{C}$. Thermograms of muscle tissue generally have three major distinguishable peaks. For instance, Wright et al. interpreted them as the denaturation of myosin $\left(60^{\circ} \mathrm{C}\right)$, sarcoplasmic

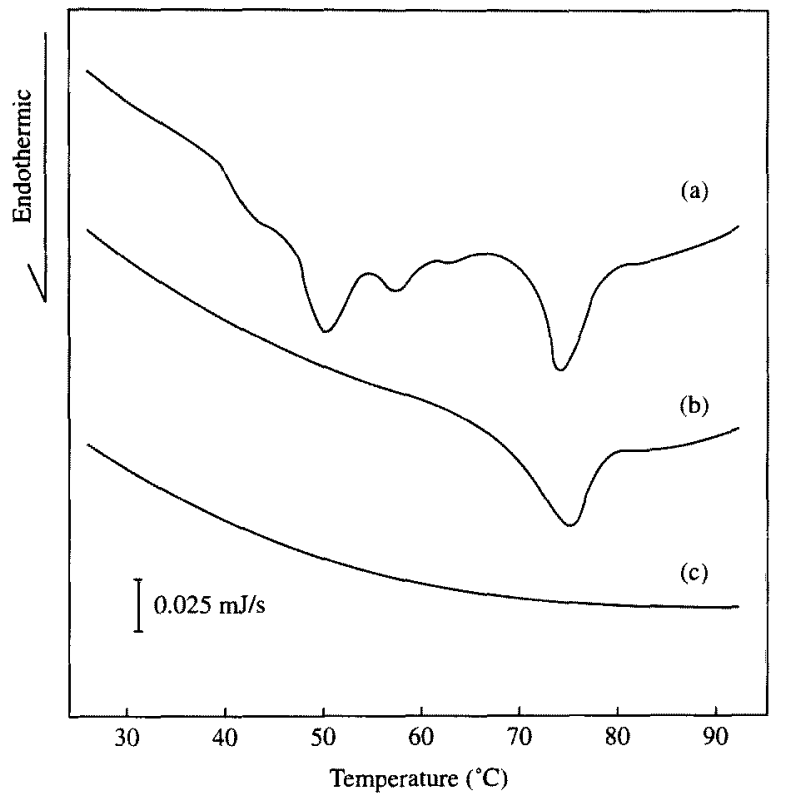

Fig. 1. DSC thermograms of "kou ika" mantle meat.

The DSC thermogram of raw meat (a), heated meat at $63^{\circ} \mathrm{C}$ for $30 \mathrm{~min}(\mathrm{~b})$, and heated meat at $80^{\circ} \mathrm{C}$ for $30 \mathrm{~min}$ (c) are composites of three replicates normalized to $15 \mathrm{mg}$ of meat.

proteins $\left(67^{\circ} \mathrm{C}\right)$, and actin $\left(80^{\circ} \mathrm{C}\right) .^{1)} \mathrm{Kijowski}$ et al. also illustrated them by the denaturation of myosin $\left(60^{\circ} \mathrm{C}\right)$, sarcoplasmic proteins $\left(70^{\circ} \mathrm{C}\right)$, and actin $\left(80^{\circ} \mathrm{C}\right) .{ }^{5)}$

On the other hand, Martens et al. ascribed them to the denaturation of myosin $\left(40-60^{\circ} \mathrm{C}\right)$, collagen $\left(56-62^{\circ} \mathrm{C}\right)$, and actin $\left(66-73^{\circ} \mathrm{C}\right) .^{3)}$ Stabursvik et al. considered that the first peak was of myosin $\left(58^{\circ} \mathrm{C}\right)$, that the second peak might be of connective tissue, collagen, sarcoplasmic proteins, and myosin $\left(65^{\circ} \mathrm{C}\right)$, and that the third peak was of actin $\left(77^{\circ} \mathrm{C}\right) .^{2)}$

The denaturation temperature of actin from different animal species was quite similar to each other $\left(77-80^{\circ} \mathrm{C}\right)$ since the difference of amino acid composition of actins from those was very little. $\left.{ }^{8}\right)$ The denaturation temperature of myosin from different animal species ranged from $40^{\circ} \mathrm{C}$ to $60^{\circ} \mathrm{C}$ since the difference of amino acid composition of myosins from those was more than that of actin. ${ }^{97}$ In any case, the first and third peaks showed the denaturation temperatures of myosin and actin, respectively.

Tuchiya et al. reported that the chemical composition and physico-chemical properties of constituent proteins for "surume ika" muscle were similar to those for rabbit muscle ${ }^{8-10)}$ Therefore, we consider that the first and third peaks on the thermograms of "ika" mantle meat are corresponded to the denaturation temperatures of myosin and actin, respectively, and that the second peak is due to the denaturation of connective tissue, collagen, sarcoplasmic proteins, and myosin.

Both the first and third peaks were overlapped with the second peak on any thermograms of rabbit, beef, fish, and chicken. ${ }^{1-4)}$ However, on the thermogram of "ika" mantle meat the third peak was not overlapped with other peaks as shown in Fig. 1-(a). The temperature of boarder between the second peak and the third peak was $63^{\circ} \mathrm{C}$ for all "ika" mantle meat. Moreover, the thermograms for all 
samples indicated that the denaturation of mantle meat had been completed up to $80^{\circ} \mathrm{C}$. Therefore, we decided that the samples were heated at $63^{\circ} \mathrm{C}$ or $80^{\circ} \mathrm{C}$ in advance of DSC measurement.

The thermogram of "ika" mantle meat heated at $63^{\circ} \mathrm{C}$ is shown in Fig. 1-(b). There was the only peak that corresponded to the third peak on the thermogram of raw "ika" mantle meat existed. It is considered that actin is almost native, but myosin, collagen, and sarcoplasmic proteins are completely denatured by heating at $63^{\circ} \mathrm{C}$ for 30 min.

Figure 1-(c) shows the thermogram of "ika" mantle meat heated at $80^{\circ} \mathrm{C}$ for $30 \mathrm{~min}$. There were no peaks in the thermogram, that is, all proteins were denatured irreversibly by heating at $80^{\circ} \mathrm{C}$ for $30 \mathrm{~min}$. All "ika" mantle meat have similar thermograms even they were heated at $63^{\circ} \mathrm{C}$ or $80^{\circ} \mathrm{C}$. Therefore, all proteins consisting of "ika" mantle meat were denatured by heating at $80^{\circ} \mathrm{C}$, but actin was not denatured at $63^{\circ} \mathrm{C}$ for all samples.

\section{Chemical Composition of Mantle Meat}

The changes of chemical composition in the "ika" mantle meat are shown in Fig. 2. Both contents of water and crude protein were slightly decreasing by heating at $63^{\circ} \mathrm{C}$ for $30 \mathrm{~min}$. In this temperature, myosin, collagen, and sarcoplasmic proteins were denatured, but actin was almost native. The water content in the "ika" mantle meat decreased by heating at $80^{\circ} \mathrm{C}$ for $30 \mathrm{~min}$. In this temperature, actin was completely denatured. Therefore, it is considered that the decreasing water content was caused by the heat denaturation of actin. Martens et al. reported that reduction in juiciness was primarily associated with actin denaturation, while cooking loss increased over the whole temperature range. It is possible that the thermally induced protein-protein aggregation of actin in the myofibrils may expel water from the myofibril, either by reducing the water binding capacity of the native gel-like structure in the myofibril, or by actual contraction of the myofibril by the formation of new cross linking. ${ }^{3)}$ It is considered that the changes of chemical composition in the "ika" mantle meat also induced a similar reaction described above by heating.

\section{Measurement of Rheological Properties}

The rheological properties of "ika" mantle meat as well

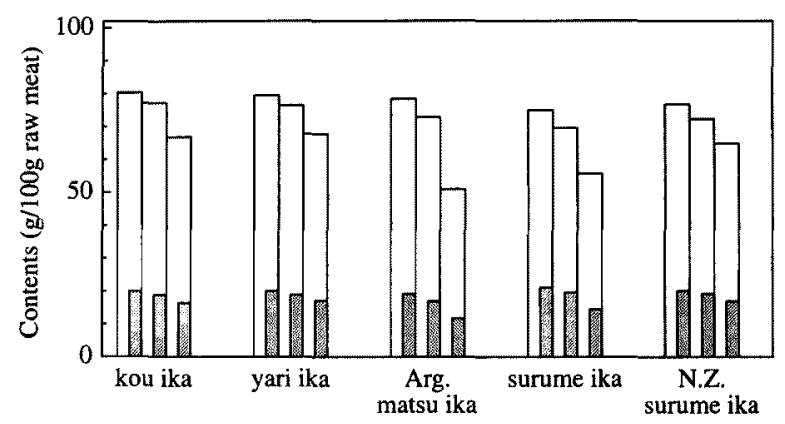

Fig. 2. Water and crude protein contents in raw and heated "ika" mantle meat.

Bars show the contents of water ( $\square$ ) and crude protein ( $\bullet$ ), respectively. The left, middle, and right bars of each sample are the values for raw meat, heated meat at $63^{\circ} \mathrm{C}$ for $30 \mathrm{~min}$, and heated meat at $80^{\circ} \mathrm{C}$ for $30 \mathrm{~min}$, respectively. as its chemical composition changed by heat treatment. At first, the rupture tests were carried out under the large deformation enough to break "ika" mantle meat. The rupture strength and the rupture power are shown in Fig. 3-(a) and (b), respectively. These values were remarkably decreased by heating without dependency of heating temperature. It is considered that the decreasing of the rupture strength and that of the rupture power were due to the denaturation of myosin, sarcoplasmic proteins, connective tissue, and collagen. We assumed that the gelatinization of collagen decreased the rupture strength and the rupture power.

The stress relaxation tests were performed without a break down of the structure of "ika" mantle meat. The elastic modulus, the relaxation time, and the viscosity of Maxwell model for "ika" mantle meat are shown in Fig. 4-(a), (b), and (c), respectively. The elastic moduli for "ika" mantle meat slightly changed by heating at $63^{\circ} \mathrm{C}$ or $80^{\circ} \mathrm{C}$ except those for "surume ika" and "New Zealand surume ika". The elastic moduli for both "surume ika" mantle meat remarkably increased by heating at $63^{\circ} \mathrm{C}$ or $80^{\circ} \mathrm{C}$. This difference between both "surume ika" and the others may be dependent on the muscle fiber structure of "ika" mantle meat. The microscopic images have revealed the structural difference of muscles in the mantle of "surume ika" and others. ${ }^{11}$

The relaxation time and viscosity for "ika" mantle meat remarkably increased by heating at $63^{\circ} \mathrm{C}$ and $80^{\circ} \mathrm{C}$, while the differences between the values of meat heated at $63^{\circ} \mathrm{C}$ and those heated at $80^{\circ} \mathrm{C}$ were small. That is, the relaxation time and the viscosity were independent of the heat temperature above $63^{\circ} \mathrm{C}$. It is consider that the relaxation time and viscosity were increased by the denaturation of myosin, sarcoplasmic proteins, connective tissue, and collagen, but they were slightly changed by the denaturation

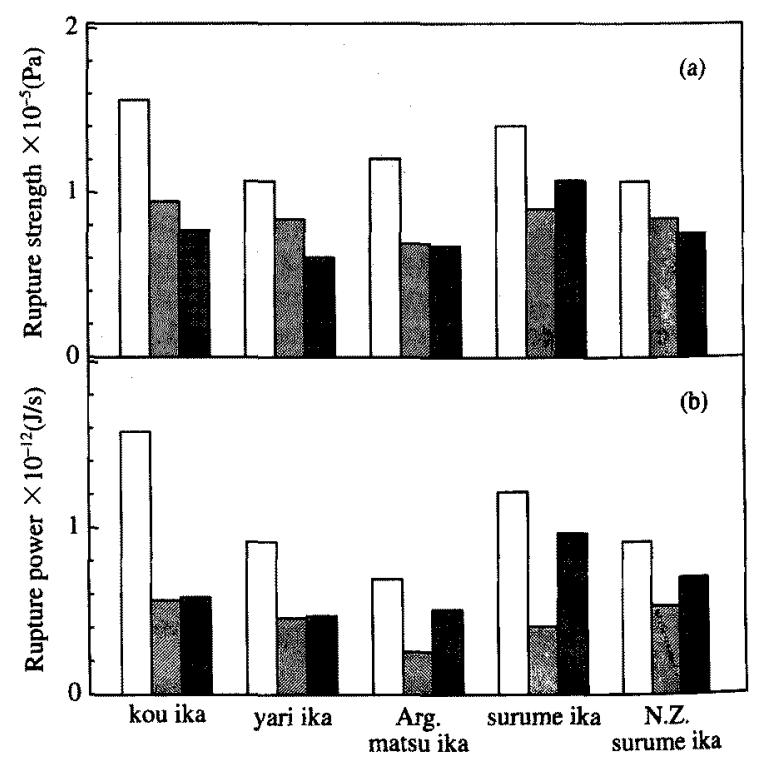

Fig. 3. Values of rupture strength and rupture power of "ika" mantle meat.

The rupture strength (a) and the rupture power (b) were estimated from sixteen replicates. The left, middle, and right bars of each sample represent the value for raw meat, heated meat at $63^{\circ} \mathrm{C}$ for 30 $\mathrm{min}$, and heated meat at $80^{\circ} \mathrm{C}$ for $30 \mathrm{~min}$, respectively. 


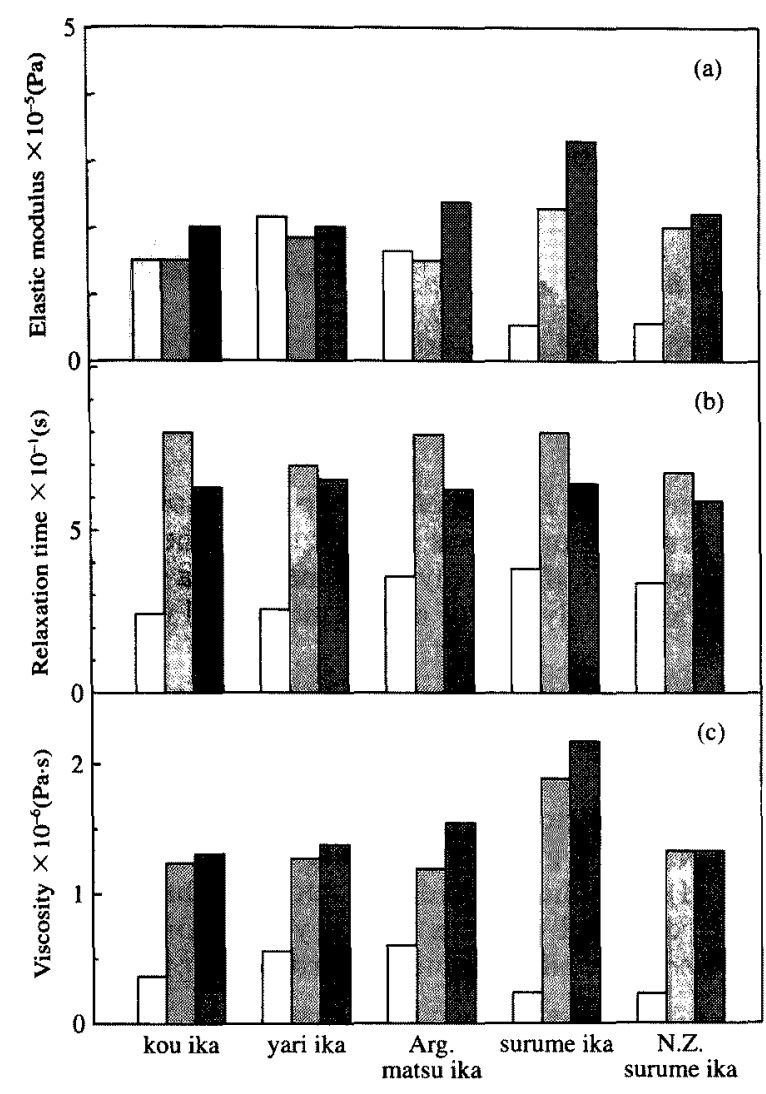

Fig. 4. Rheological properties obtained from stress relaxation tests. The elastic modulus (a), the relaxation time (b), and the viscosity (c) of Maxwell model were estimated from sixteen replicates. The left, middle and right bars of each sample represent the value for raw meat, heated meat at $63^{\circ} \mathrm{C}$ for $30 \mathrm{~min}$, and heated meat at $80^{\circ} \mathrm{C}$ for $30 \mathrm{~min}$.

of actin.

In both results of the chemical composition and the rheological properties for "ika" mantle meat, the relationships between the content of crude protein and the instantaneous elastic modulus showed a positive correlation $\left(r^{2}=0.9668\right)$ by heating at $63^{\circ} \mathrm{C}$ (Fig. 5-b). The relationships between them were not observed in the case of raw meat, (Fig. 5-a). Furthermore, the correlation between them was disappeared by heating at $80^{\circ} \mathrm{C}$, (Fig. 5-c). The water content and the crude protein content slightly changed by heating at $63^{\circ} \mathrm{C}$, and the actin was almost native. Therefore, those relationships were not related to the water content.

We presume that the relationships between the crude protein content and the instantaneous elastic modulus were associated with the amount of remaining native actin.

Acknowledgments This work was supported in part by a Grant-in-Aid for Scientific Research Promotion from the Ministry of Education, Science, and Culture of Japan, for which we are thankful.

\section{References}

1) D. J. Wright, I. B. Leach, and P. Wilding: Differential scanning calorimetric studies of muscle and its constituent proteins. J. Sci. Food Agric., 28, 557-564 (1977).

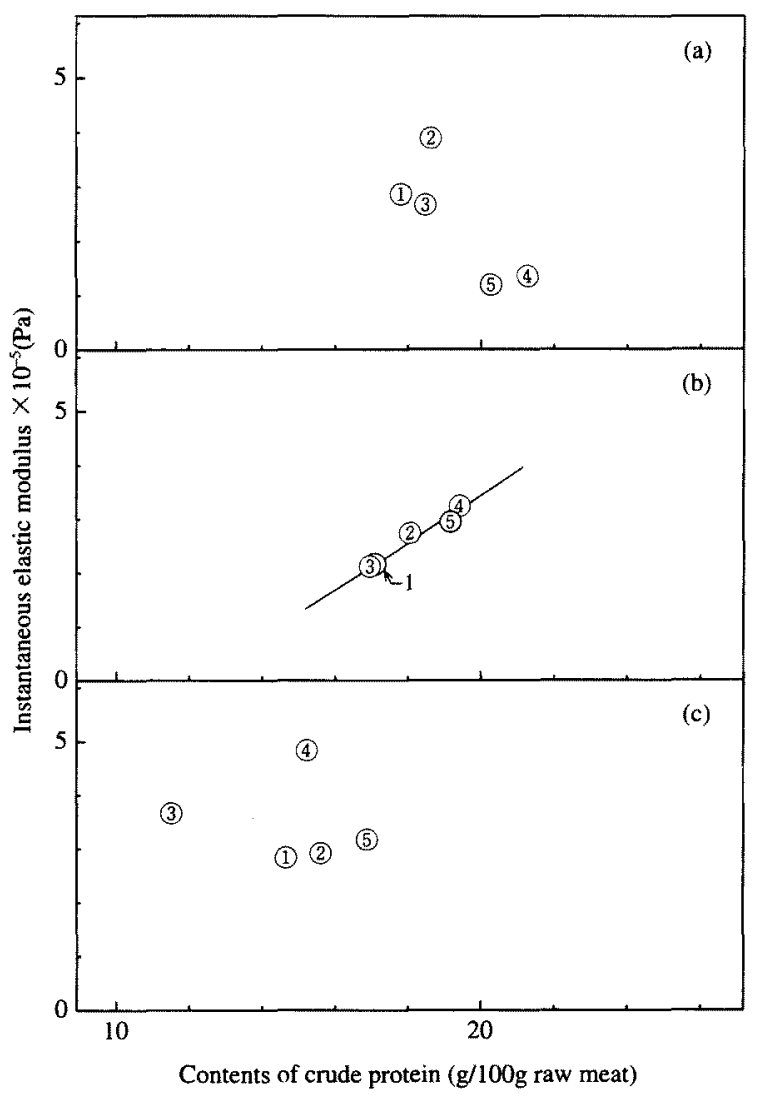

Fig. 5. Relationships between instantaneous elastic modulus and content of crude protein.

Raw meat, (a); heated meat at $63^{\circ} \mathrm{C}$ for $30 \mathrm{~min}$, (b); heated meat at $80^{\circ} \mathrm{C}$ for $30 \mathrm{~min}$, (c). Circled numbers indicate the type of "ika" mantle meat: "kou ika", (1); "yari ika", (2); "Argentine matsu ika", (3); "surume ika", (4); "New Zealand surume ika”, (5).

2) E. Stabursvik and $\mathbf{H}$. Martens: Thermal denaturation of proteins in post rigor muscle tissue as studied by differential scanning calorimetry. J. Sci. Food Agric., 31, 1034-1042 (1980).

3) H. Martens, E. Stabursvik, and M. Martens: Texture and colour changes in meat during cooking related to thermal denaturation of muscle proteins. J. Texture Studies, 13, 291-309 (1982).

4) T. Saito, N. Iso, H. Mizuno, and Y. Mochizuki: Thermal denaturation of fish muscle and myofibrillar proteins. Repts. Prog. Polym. Phys. Japan, 27, 745 746 (1984).

5) J. M. Kijowski and M. G. Mast: Thermal properties of proteins in chicken broiler tissues. J. Food Sci., 53, 363-366 (1988).

6) Y. Mochizuki, H. Mizuno, H. Ogawa, K. Ishimura, H. Tsuchiya, M. Fukuzawa, and N. Iso: Rheological properties of cuttlefish and squid raw meat. Fisheries Sci., 60, 555-558 (1994).

7) A. V. Tobolsky and K. Murakami: Existence of a sharply defined maximum relaxation time for monodisperse polystylene. $J$. Polymer Sci., 40, 443-446 (1959).

8) T. Tsuchiya, H. Suzuki, and J. J. Matsumoto: Physico-chemical and biochemical properties of squid actin. Nippon Suisan Gakkaishi, 43, 1233-1240 (1977).

9) T. Tsuchiya, N. Yamada, and J. J. Matsumoto: Physico-chemical properties of squid myosin. Nippon Suisan Gakkaishi, 44, 181-184 (1978).

10) N. Horie, T. Tsuchiya, and J. J. Matsumoto: Studies on ATPase activity of actomyosin of squid mantle muscle. Nippon Suisan Gakkaishi, 41, 1039-1045 (1975).

11) M. Suyama, S. Kounosu, M. Hamabe, and Y. Okuda: Ika no riyou (Utilization of cuttlefish and squid), Kouseisya-kouseikaku, Tokyo, 1980 , pp. 38-51 (in Japanese). 